Данијела Митровић

Институт за

књижевност и уметност

e-mail: danijelamitrovic.16@gmail.com
930.85(497.1:410)

https://doi.org/10.18485/ai_lik.2020.6.10.8

Оригинални научни рад

\title{
ПОВЕРЉИВИ ДОКУМЕНТИ О КУЛТУРНОЈ САРАДЬИ ФНРЈ СА ВЕЛИКОМ БРИТАНИЈОМ
}

У раду се доноси документација која је доступна у Фонду Савета за науку и културу Владе ФНРЈ. Коресподенција која је вођена са Амбасадом ФНРЈ у Лондону пружа јасан увид у разлоге одређеног поступања југословенске Владе, а објашњења која су остављена у писмима су сведочанство томе на који су начин желели да представе ФНРЈ и у којој мери су полагали на важност добре слике о држави у инострантсву. Трагови опресивности и строге контролисаности система ван државе видљиви су у вођењу иностране политике и то се управо ставља у фокус рада. Циљ овог рада јесте покушај анализе докумената ради указивања на потенцијалне узроке специфичног поступања Владе ФНРЈ, као и истицање најбитнијих аспеката културне делатности Амбасаде ФНРЈ у Лондону.

Кључне речи: Влада ФНРЈ, Амбасада ФНРЈ, културолошке везе, музичке и сценске уметности, инострана политика

Фонд Савета за културу и науку Владе Федеративне Народне Републике Југославије може се посматрати као повлашћена тачка из које се пружа знатно боља перспектива уколико желимо да сагледамо како је у том кратком временском периоду од 1950. до 1952. године конституисана политика ФНРЈ у погледу културе и науке, али кроз призму ове две врло уско одређене области можемо видети наговештаје из знатно ширег средишта из којег су ове две гране еманиране. Иако грађа није комплетна и недостају извесна документа која би у многим случајевима дала коначни печат 
читавој ситуацији, ${ }^{3}$ чак и наговештаји, као и оно што постоји у целовитом облику, пружају, можемо рећи, јасан увид у општу слику спољне политике ФНРЈ.

Важност координације Савета за науку и културу и Амбасаде ФНРЈ у Великој Британији у циљу адекватне „kulturne propagande“ ФНРЈ у Великој Британији истиче се већ у првом документу на који наилазимо у поменутом Фонду. ${ }^{4}$ У њему се такође наглашава да је та усклађеност неопходна и због претходних пропуста (који су таксативно наведени и има их осам), што на самом почетку указује на мањкавост у дотадашњем раду и важност исправљања грешака у циљу што бољег представљања ФНРЈ у Великој Британији, ${ }^{5}$ а на томе се врло предано радило. На основу прегледане документације може се закључити да је свеукупна политика културног представљања ФНРЈ у Великој Британији била пажљиво вођена, али је увек била неминовно ограничена материјалним условима и средствима којима су располагали. У једном од таквих примера, гостовање фолклорног ансамбла на Ланголенском музичком фестивалу (Llangollen International Musical Eisteddfod) 1951. године умало није отказано јер су те године поплаве нанеле велику штету ФНРЈ и нису имали буџет да пошаљу представнике фолклорног ансамбла. ${ }^{6}$ Осим тога, брижљиво се одређивало шта ће бити презентовано у иностранству, али и шта ће бити прихваћено у самој земљи. Једна од првих битних области јесте музичка и сценска ${ }^{7}$ уметност.

3 Један од таквих примера је и случај Џона В. Н. Холмса (John W. N. Holmes) који је требало да дође у Југославију на студије у трајању од годину дана, и иако му је све било одобрено од стране Универзитета у Загребу, није добио визу и испоставило се да је, како обавештава Савет за културу и науку, све то потврђено само провизорно, остајемо ускраћени за податак да ли му је октобра 1952. године заиста одобрено да дође или није (Архив Југославије /даље: АJ/, Фонд Савета за културу и науку Владе ФНР /даље: 317/-5-646-650), а од исхода свакако зависи и квалификација овог случаја.

4 АЈ 317-5-374.

5 AJ 317-5-375-378.

6 AJ 317-5-442.

7 Пронађен је само један податак да постоји могућност да гостује British Drama League y: AJ 317-5-516. 


\section{1 Музичка и сценска уметност}

Музичка уметност је била врло плодно тле за сарадњу и представљање ФНРЈ у Великој Британији. Преко музике наших уметника Британци су имали прилику да се боље упознају са културом ФНРЈ. Вредно помена је и то да се у случају презентовања уметника и те како водило рачуна о политички погодним појединцима. Наиме, при одабиру представника за концерте које је организовао пијаниста Кендал Тејлор (Kendal Taylor) на предлог Амбасаде да представнице буду Мелита Лорковић и Драгица Мартинис, начелник Одељења за научне и културне везе са иностранством, Ф. Дреновец, изјављује да ће заобићи њих две и то „prvu iz pol. razloga ${ }^{8}$ drugu kao dobru opersku, ali slabiju koncertnu pevačicu“." Овај моменат политичке неподобности често ће се понављати, ако не отворено као у овом случају, онда суптилним указивањем да је неко неадекватан за представљање у иностранству. Пласирање класичне музике, ${ }^{10}$ али и народних песама које су нешто новијег датума, углавном се одвијало преко откупљивања ауторских права и издавања у иностранству. Поред тога, Велика Британија је исказивала интересовање и за упознавање са југословенским фолклорним играма, које је и сама Југославија истицала као свог представника у иностранству. Фолклорни ансамбли су наступили чак два пута током 1951. године и то не само у Великој Британији, него и у Холандији, Белгији, Француској, али и Западној Немачкој. ${ }^{11}$ У том документу најбитније ставке подвучене

8 Због активног учествовања њеног девера Младена у покушају извршења државног удара и преласка са НДХ на страну Савезника били су јој забрањени јавни наступи 1944. године и из овог податка можемо видети да је та забрана била на снази и по завршетку Другог светског рата (https://hr.wikipedia. org/wiki/Melita_Lorkovi\%C4\%87).

9 AJ 317-5-396.

10 Опере су им такође биле врло интересантне, посебно „Охридска легенда“ Стевана Христића, и њу су радо играли када би британски представници долазили у ФНРЈ, као што се може видети у: АЈ 317-5434.

$11 \quad$ AJ 317-5-504-507. 
су црвеном оловком, највероватније да би се истакло шта је оно што је најхитније, али такође привлачи пажњу да се поред параграфа у којем се наводи да би требало видети да ли је дозвољено да ансамбл наступи у Западној Немачкој стоји слово „В“ са знаком узвика. У том тренутку начелница Одељења за научне и културне везе са иностранством била је Ванда Новосел, тако да то слово највероватније значи да се то питање мора упутити на највишу инстанцу ради подробнијег разматрања.

\section{2 Размена студената и стручних кадрова}

Позиви на међународне конференције нашим стручњацима и професорима били су у то време бројни: за енглески језик, ${ }^{12}$ шумарство, ${ }^{13}$ грађевинарство, ${ }^{14}$ шекспиролошке студије ${ }^{15}$ итд. Прве стипендије и позиви на усавршавање обезбеђене су преко Британског Савета (British Council) 1950. године у виду „6 посетилачких недеља за научне и културне раднике“, а у том документу Ванда Новосел обавештава Комитет за заштиту здравља да је њима стављено на располагање три недеље.. ${ }^{16}$ Исте године се покреће и иницијатива размене лектора од којих би један Југословен био постављен као лектор у Школи за славенске језике $\mathrm{e}^{17}$ у Лондону, док би један енглески лектор могао бити постављен на неки од домаћих универзитета. ${ }^{18}$ Постојала је и стипендија Фонда српског посланика преко које је 11 студената и дипломираних студената одабрано да оде у Енглеску, ${ }^{19}$ а такође је и сам

\footnotetext{
12 AJ 317-5-385.

13 AJ 317-5-389.

14 AJ 317-5-405.

15 AJ 317-5-650-651.

16 AJ 317-5-410.

17 18. 5. 1950. године овој институцији је послато 189 наслова на српскохрватском језику, као и примерци два најистакнутија југословенска филолошка часописа, као што се види у: АЈ 317-5-387.

18 AJ 317-5-411.

19 AJ 317-5-550.
} 
Савет за науку и културу делио стипендије. ${ }^{20}$ Осим стипендија које су дељене нашим студентима, ${ }^{21}$ Савет је установио и три стипендије које је делио за дипломиране студенте из Велике Британије и то за кандидате које интересуje „slavistika i naša srednjovekovna umetnost“, као и „осеanografija i narodna muzika i folklor“, али је такође додато и да је битно да се поред осталих података достави и политички став кандидата, као и мишљење амбасадора. ${ }^{22}$ Што се тиче стручњака који су посећивали ФНРЈ, олакшице и стипендије су одобраване углавном онима који су имали некакво знање српскохрватског језика, али и онима који су се интересовали за гране које су биле од посебне важности за промовисање у ФНРЈ. Тако, на пример, енглески глумац и предавач Хју Милер (Hugh Miller) изражава жељу да дође у ФНРЈ како би одржао предавања на енглеском о глуми, али му се не одобрава захтев уз образложење да би публика била незаинтересована због непознавања енглеског језика. ${ }^{23}$ Нешто касније исте године наилазимо на један занимљив документ у којем се радници из НР Хрватске упућују на курс учења енглеског језика, ${ }^{24}$ али уз напомену да су свих 39 кандидата чланови СКJ-a. ${ }^{25}$ Насупрот примеру Хјуа Милера, налазимо на примере Хебе Спол (Heba Spaull), која би желела да се упозна са начином живота и функционисања југословенских задруга. ${ }^{26}$ Њој је боравак дозвољен, али се наводи да ће бити потребно да се детаљније обавесте о њеним политичким ставовима и ставу према ФНРЈ, ${ }^{27}$ потом пример Гатрија Mоара (Guthrie Moir), руководиоца St. John Ambulance Brigade који жели

20 AJ 317-5-553.

21 О којима су морали да примају извештаје од амбасадора, као што се види у: АЈ 317-5-569.

22 AJ 317-5-629.

23 АЈ 317-5-573-610.

24 Ранији покушаји штампања уџбеника за учење енглеског језика (1950. године, у односу на 1952. годину када се упућују на курс учења енглеског језика), нису уродили плодом, као што се види у: АJ 317-5409.

25 АЈ 317-5-676.

26 Очигледно је у питању упознавање са моделом тек уведеног радничког самоуправљања.

27 AJ 317-5-494. 
да се упозна са методама рада са југословенском омладином, ${ }^{28}$ као и Мајкла Харта (Michael Hart) који је 1952. године са групом ђака желео да посети ФНРЈ како би се упознали са радом политичких и педагошких установа, али такође и са фабрикама и начином рада у њима. ${ }^{29}$ Може бити интересантно такође споменути да Британци исказују интересовање за упознавање са педагошким системом у ФНРЈ, али да њихови захтеви махом остају неиспуњени. Један од уредника Годишњака о школсииву (The Year Book of Education) ce 1951. године обратио Савету како би добили текст о југословенској просвети за 1952. годину. Иако је било обећано да ће тај текст написати и послати Иво Фрол, помоћник министра у Савету за културу и науку, тај текст никада нису примили. ${ }^{30}$ Поучени тим примером, следеће године су тражили да директно ступе у контакт са писцима текстова и затражили су да се напише пет различитих текстова како би имали увид за различите републике, али су им рекли да ће бити довољан само један, јер је систем униформан у свим републикама. ${ }^{31}$ Фестивал васпитног (едукативног) филма је упутио позив „Југославија филму“ да учествује са једним таквим примером филма, али су одлучили да ипак не учествују јер „nе raspolažemo sa vaspitnim filmovima sa kojima bismo mogli izaći u inostranstvo".32

28 AJ 317-5-563.

29 AJ 317-5-663-664.

30 AJ 317-5-459-461.

31 AJ 317-5-645.

32 AJ 317-5-522. 


\title{
2. Поверљиве везе са Великом Британијом
}

\section{1 Документи у вези са музичком и сценском уметношћу}

\author{
1. \\ (4. 7. 1950; писмо - машинопис ${ }^{33}$; Лондон) \\ Embassy of the Federative People's \\ Republic of Yugoslavia. \\ Information Office: \\ 195, Queen's Gate, \\ London, S.W.7.
}

4. VII 1950.

Predmet: Muzicka aktivnost.

u iducoj sezoni.

DIREKCIJI ZA INFORMACIJE

Za Min. za nauku i kulturu

B e o grad

Pre svoga odlaska u Jugoslaviju maja meseca, Kendal ${ }^{34}$ Taylor, pijanista, ${ }^{35}$ je uputio pismo Britansko jugoslovenskom drustvu prijatelja u kome predlaze da Drustvo uzme pokroviteljstvo nad prvim solictickim koncertima jugoslovenskih kompozitora. $\mathrm{Na}$ taj nacin bi nasi umetnici mogli da se predstave engleskoj publici i docnije dobili angazmane za gostovanja u Operi i sl.

Sto se tice drugog predloga (organizovanje koncerta) Kendal Taylor je ponudio da uzme ucesa na koncertu bez nagrade. Prihod sa ovoga koncerta sluzio bi za troskove oko organizovanja solistickih koncerata.

33 Сви документи у овом раду су машински куцани.

34 Његово име се кроз текст различито транскрибује, али ми ћемо се држати овог стандарда.

35 У оригиналу стоји „ріanista“. 
Drustvo je pristalo na ove predloge i sada razmatra pitanje sale i vremena odrzavanja koncerata. Kako je jedina pogodna sala za ovakve koncerte Wigmore Hall, vec uveliko angazovana do Bozica, trebalo bi bar provizorno zauzeti salu i to za pocetak novembra i za mart mesec.

Pitanje ostaje koji bi od nasi[h] umetnika mogli da dodju i za to molimo vas pomoc i najhitniji odgovor kako bi blagovremeno pripremili ove koncerte. Nase misljenje je da bi najpogodniji bili Dragica Martinis i pijanistkinja Lorkovic. ${ }^{36}$

Druga stvar koju je Kendal Taylor pokrenuo jeste pitanje gostovanja dirigenta J. Barbiroli-a. Barbiroli je vrlo rado prihvatio ideju gostovanja u Jugoslaviji. Medjutim njegov predlog je sledeci: On momentalno pregovara sa Austrijom za gostovanje u prolece 1951, a takodje i sa Italijom u isto vreme. U tom slucaju on bi vrlo rado dosao i u Jugoslaviju (Barbiroli bi gostovao zajedno sa svojim orkestrom-Halle). Troskovi puta bi bili minimalni jer bi Barbiroli morao i onako da dodje do Graca o svom trosku ili trosku Austrije. Iako njegovi pregovori za gostovanje Hala orkestra u Austriji i Italiji još nisu zavrseni, mi bi trebalo da znamo odmah da li u principu mozemo da prihvatimo ovaj Barbiroliev predlog. Molimo vas da nas sto pre izvestite o vasoj principijelnoj odluci.

II. Kendal Taylor je inace bio vrlo zadovoljan svojom posetom Jugoslaviji, ali se nama cini da je ovoga puta finansijska strana posete dosta slabo organizovana. Taylor je naime dobio sumu od 156.000 dinara za odrzanih 13 koncerata. Na svojoj turneji po Jugoslaviji Taylor je potrosio na putne troskove i hotele oko 70.000 dinara. Verujemo da je ovo pitanje moglo i na neki drugi način da se resi a ne da se ostavi Tayloru da vrsi sam isplatu troskova turneje.

Tayloru je obecano da ce mu se jedan deo novca $-24.000 \mathrm{~d}$. - dostaviti u funtama. Ostali deo novce - $85.000 \mathrm{~d}$. je jos uvek u Jugoslaviji. Od ove sume Taylor ima nameru da potrosi $30.000 \mathrm{~d}$. na svoje letovanje u Sloveniji a moli da mu se ostatak od $65.000 \mathrm{~d}$. pretvori u funte i isplati u jednom duzem i neodredjenom roku,

36 У писму је грешком написано „Lotkovic“, што се види из одговора на ово писмо. 
eventualno u ratama. On tvrdi da bi za isto vreme u Engleskoj dobio otprilike ${ }^{37}$ tu sumu novca. Taylor na ovome ne insistira narocito, ali imajuci u vidu njegove razne usluge smatramo da bi bilo pravilno da mu se ova suma isplati u funtama.

Tayloru je u razgovoru sa drugom Drenovcem i $\mathrm{M}$. Horvatom obecano da ce iduce sezone na jesen moci da svira Blissov koncert u Zagrebu, koji ovoga puta nije mogao biti odrzan. Kendal Taylor moli da vas izvestimo da je on slobodan u vreme od 10[.] decembra do početka januara i da je spreman da krajem decembra dodje u Jugoslaviju.

Molimo vas da nam sto hitnije date svoje misljenje o gornjim predlozima kako bi se blagovremeno izvrsile sve pripreme.

$$
\text { S.F.-S.N. }
$$

[potpisano drugim prezimenom] /za/ /Al. Sokorac/ Savetnik za štampu.

$$
\text { (AJ, 317-5-394-395) }
$$

2.

(26. 7. 1950; писмо; Београд)

\author{
SAVET ZA NAUKU I KULTURU \\ VLADE FNRJ \\ V. br. /pov/ \\ 26. VII [19]50[.] \\ BEOGRAD \\ $\mathrm{FD} / \mathrm{M}$
}

AMBASADA FNRJ

$\underline{\mathrm{LONDON}}$

37 У оригиналу пише „od prilike“. 
Potvrdjujemo prijem Vašeg pov. br. 651 od 4.VII t. g. i dajemo po pojedinim pitanjima sledeće odgovore:

1/ G. Kendal Taylor upoznao nas je povodom svog boravka u FNRJ sa svojim predlozima za muzičke priredbe Britansko-jugoslovenskog društva i mi smo se složili sa njegovim gledalištem. On je svoje predloge ogradio na interne koncerte za članove društva dok smo mi prelagali da se na te koncerte pozovu i muzikolozi, muzički kritičari, i umetnički rukovodioci ansambla, itd. čega G. Taylor nije u celini primio. Nismo mogli utvrditi zašto je tako usko postavljao stvar. Što se tiče dolaska naših umetnika da učestvuju na tim koncertima, dali smo Tayloru konkretna obećanja. Mislimo da dolaze u obzir M. Bugarinović, Anita Mezetova, Marijana Radev, Jože Gostić, Stanoje Janković, Vlado Ruždjak, Tomislav Neralić od pevača, Ivo Maček, Anton Trošt i Dora Gušić od pijanista, Karel Rupel kao violinista i Anton Janigro kao čelista. Do sada su pomenuti umetnici još slobodni, ali ne bi mogli vezati odredjeno njihovih termina dok ne utvrdite vremena koncerta, jer svi pomenuti imaju različite ponude koje moraju uskladjivati sa svojim obavezama u zemlji. Zbog toga možete iz gornjih imena izvršiti izbor čim utvrdite termine i mi se obavezujemo da će odredjeni umetnici biti oslobodjeni svih drugih obaveza kako bi mogli učestvovati u Londonu. Kao što vidite, obišli smo Melitu Lorković i Dragicu Martinis: prvu iz pol. razloga drugu kao dobru opersku, ali slabiju koncertnu pevačicu.

2/ Što se tiče gostovanja Barbirollia, postavlja se dakle u prvom redu gostovanje njegovog orkestra. Ako nisu u pitanju devizna sredstva, što ne verujemo, predlog je interesantan. Ako su u pitanju devizne obaveze, ne pokrećite ništa. U Vašu informaciju Vas izveštavamo da je orkestar bečkih simfoničara priredio za 6 dana 6 koncerata i da smo im platili u devizama maksimum, 60.000 din. Možda bi službeni engleski krugovi bili politčki zainteresovani da dodje do gostovanja orkestra. U tom slučaju mi bismo platili sve dinarske iznose i put, a službeni britanski krugovi bi dali subvenciju sa druge strane. Ako je moguće da se Barbirollievo gostovanje ostvari bez orkestra uz povoljne devizne uslove, molimo, pregovarajte dalje. Termin 16. decembar je povoljan.

3/ Što se tiče gostovanja Kendala Taylora i njegovih uslova, mislimo da su bili jako povoljni i da je pravilno da su bili postavljeni 
tako. Nemoguće je da mu ne bi platili najvišu stopu, a to je bilo moguće samo pod uslovom da je izdržavanje platio sam. To što je utrošio 70.000 din., on taj iznos nije utrošio samo za sebe, nego i za svoju prijateljicu koju je bogato častio. Iznenadili su nas njegovi visoki devizni zahtevi. Ako bi se to znalo na početku gostovanja ne bi mu se moglo odobriti toliki broj koncerata. Poslovnica je tražila za deviznu isplatu vanredni kredit i čim taj bude odobren, novac će biti poslat.

4/ Ostajemo pri obećanju za Blissov koncert. Termin posle 10[.] decembra je povoljan. Molimo da Taylor stavi svoje finansijske ${ }^{38}$ uslove. Bez previziranja tih uslova ne možemo dati druge konkretne obaveze, jep ne želimo da dodjemo ponovo u situaciju u kojoj smo bili prilikom zadnjeg Taylorovog gostovanja zbog deviza.

\section{S.F-S.N.!}

Načelnik odeljenja za naučne i kulturne veze sa inostranstvom [potpisan] /F. Drenovec/

(AJ, 317-5-396)

3.

(8. 11. 1950; писмо; Београд)

SAVET ZA NAUKU I KULTURU

VLADE FNRJ

Pov. V. br. /1168/

8. XI 1950[.]

BEOGRAD

MG/SV

AMBASADA FNRJ

L O N D N

38 У свим документима се доследно изоставља „ј“у овој речи. 
U vezi vašeg predloga da na priredbi Društva britansko jugoslovenskog prijateljstva 6[.] februara iduće godine nastupe naši umetnici, saopštavamo vam sledeće :

Sa principijelne strane smatramo da bi nastup na ovakvoj priredbi bio od koristi za one naše dobre umetnike koji u internacionalnom muzičkom svetu još nisu poznati, a sa ovakvim istupanjem postigli bi prvi publicitet $u$ inostranstvu. Iz ovih razloga smatramo da nema potrebe da uputimo na koncert Dragicu Martinis ni Doru Gušić / koju smo spomenuli u telegramu /, ni Mačeka, a Melita Lorković iz drugih razloga ne bi došla u obzir.

Polazeći sa ovog gledišta, rešili smo da bi na toj priredbi mogli nastupiti operska pevačica Valerija Hejbalova, / sopran / i Vladimir Ruždjak, / bas - bariton /. Poslednji je mlad umetnik i po oceni naših stručnjaka i koncertne publike zbog svog kvaliteta on ima perspektive da i u muzičkom svetu postigne priznanje. Pošto u ovom slučaju ne bi bilo pijaniste ${ }^{39}$ trebalo bi da se nadje tamo. Možda bi mogao na koncertu istupiti i Kendall Taylor sa nekim samostalnim tačkama a uz to i preuzeti klavirsku pratnju pevača.

Imajući u vidu cilj, koji hoćemo da postignemo ovim gostovanjem, želeli bi[smo] imati garanciju da koncert bude dobro pripremljen, kako sa tehničke strane, tako i da bude sastav publike onakav, da bi gostovanje imalo odgovarajući efekat. Trebalo bi, da to bude publika sa muzičkom kulturom i da budu pozvane i pojedine ličnosti koje imaju uticaja u muzičkom svetu.

$\mathrm{Ne}$ bi želeli prejudicirati stvari, ali pošto su u nekim zemljama, gde smo organizovali slične koncerte, oni bili prilično loše pripremljeni, molimo vas da unapred date vaše predloge, kako zamišljate organizaciju ove priredbe / u kakvoj sali će biti koncert, da li će se štampati programi, prodavati ulaznice i kome nameravate uputiti pozivnice itd./.

Što se tiče finansijske strane, $\mathrm{mi}$ bi[smo] umetnicima platili putne troškove i dnevnice ali neće dobiti honorara. Ostale režijske ${ }^{40}$ troškove treba da snosite vi.

Kako bi mogli na vreme pristupiti pregovaranju sa umetnicima i odrediti program prema vašim datim sugestijama, molimo vas da nam što pre date odgovor po svim pomenutim pitanjima.

39 У оригиналу стоји „pianiste“.

40 У оригиналу пише „režiske“. 
S. F. - S. N.

\author{
Načelnik Odeljenja \\ za naučne i kulturne veze \\ sa inostranstvom \\ [potpisana] /V. Novosel/
}

(AJ, 317-5-428)

\title{
2.2 Документи у вези са разменом студената и стручних кадрова
}

1.

(29. 7. 1950; писмо; Београд)

\author{
SAVET ZA NAUKU I KULTURU \\ VLADE FNRJ \\ V. br. pov. /404/ \\ 29. VII [19]50[.] \\ BEOGRAD \\ $\mathrm{FD} / \mathrm{M}$
}

\section{AMBASADI FNRJ LONDON}

Sa raznih strana smo dobili predlog da bi trebalo pronaći jednog lektora kojega bi namestili na Školi za slavenske jezike u Londonu kao lektora za srpskohrvatski jezik i književnost. Taj lektor mogao bi obavljati i neka druga pitanja naših kulturnih veza sa Engleskom. Kao vanredno važno mogao bi preuzeti mesto Subotića u Fondu srpskog poslanika.

S druge strane nama su Englezi ponudili lektora engleskog jezika na jedan od naših univerziteta. Taj predlog bio nam je postavljen tako sa strane British Council-a u Beogradu kao i od gdje OTI Filips, kada je boravila u Beogradu. 
Smatramo da bi bilo od značaja ako bi plasirali našeg čoveka kao nastavnika Škole za slavističke jezike i molimo da pokrenete najozbiljnije te razgovore tako na Školi za slavističke jezike kao i da poduprete nastojanja British Council-a da se na bazi reciprociteta postavi naš lektor akademskog ranga na Školi slavističkih jezika $\mathrm{u}$ Londonu.

\section{S.F.-S.N.!}

Načelnik Odeljenja za naučne i kulturne veze sa inostranstvom, [potpisan] (F. Drenovec)

(AJ, 317-5-411)

2.

(20. 7. 1951; извештај; Београд)

\section{SAVET}

$\operatorname{xxxxxxx}$

Pov. v. 373

20. VII 1951[.]

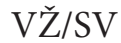

\section{GENERALNOM SEKRETARU VLADE FNRJ $\underline{B \text { E O G R A D }}$}

Na predlog Saveta za nauku i kulturu Vlade FNRJ tutori Fonda srpskog poslanika u Londonu dodelili su stipendije sledećim jugoslovenskim studentima odnosno diplomiranim studentima:

1. KSENIJI ANASTASIJEVIĆ, lektoru Novinarske i diplomatske visoke škole u Beogradu, sa stanom u Maršala Tolbuhina ulica 78/II;

2. LJILJANI GRDJIĆ, lektoru engleskog jezika na Visokoj saobraćajnoj školi u Beogradu, sa stanom u Bulevaru Jugoslovenske Armije 75; 
3. MARIJI MILADINOVIĆ, studentu Filozofskog fakulteta u Beogradu, sa stanom u ulici Lole Ribara broj 6 u Beogradu;

4. OLGI LAZAREVIĆ, studentu Filozofskog fakulteta $\mathrm{u}$ Beogradu, sa stanom br. 4 u Zoološkom vrtu;

5. DJORDJU POZNANOVIĆU, službeniku Ministarstva inostranih poslova, sa stanom u Varšavskoj br. 42;

6. ZORKI STOJADINOVIĆ, diplomiranom studentu Filozofskog fakulteta u Beogradu, sa stanom u Koče Kapetana 15, Beograd;

7. RANKI KUJIĆ, diplomiranom studentu Filozofskog fakulteta u Beogradu, sa stanom u Bulevaru Crvene Armije 167/a u Beogradu;

8. NATALIJI BIANCHI, pripravniku profesora u Novom Mestu kod Ljubljane;

9. IVU VIDANU, asistentu Novinarske škole u Zagrebu;

Pored ovih kandidata, na predlog tutora Fonda srpskog poslanika Savet za nauku i kulturu Vlade FNRJ složio se da se produži i u ovoj školskoj godini stipendija drugaricama ZORKI ŠOŠKIĆ i DRENKI OPALIĆ zbog rezultata koje su pokazale za vreme svog prošlogodišnjeg studija u Engleskoj.

Svih 11 stipendista primaju mesečne stipendije Fonda srpskog poslanika i dodatak uz stipendiju od strane Saveta za nauku i kulturu Vlade FNRJ u mesečnom iznosu od 6.- funti.

Molimo za Vašu saglasnost da imenovani putuju u inostranstvo.

\section{$-2-$}

Imenovani bi boravili u Engleskoj u toku školske 1951/52[.] godine. Za Englesku putuju početkom meseca septembra 1951[.] godine. Putne troškove plaća Savet za nauku i kulturu Vlade FNRJ.

S. F. - S.N.

M I N I S T A R, [potpisan] / R. Čolaković / (AJ, 317-5-550-551) 
3.

(26. 5. 1952; писмо; Београд)

V. /Pov. 357/

26. maj [195]2[.]

Pošt. fah: 106

Tel. 24-531/222

$\mathrm{MR} / \mathrm{ZG}$

Predmet: stipendije za engleske studente.

\section{A M B A S A D A FNRJ \\ za druga Šokorca \\ $\underline{\mathrm{LONDON}}$}

Savet za nauku i kulturu Vlade FNRJ doneo je odluku da se stave na raspoloženje britanskim studentima tri stipendije za školsku 1952/53[.] godinu. Predstavnik Britanskog Saveta u Jugoslaviji gospodin Sutclif je ovu našu oduku vrlo zadovoljno primio i po tom pitanju smo sa njime imali razgovor. On se složio sa svim našim uslovima kod dodeljivanja stipendija stranim državljanima, samo što se tiče izbora sugerirao nam je da bi najbolje bilo ako bi pisali vama i da vi sa Britanskim Savetom u Londonu razmotrite to pitanje, uz pomoć Univerziteta i stručnih ustanova. Kod davanja predloga potrebno je da Univerzitet ili dotična naučna ustanova dadu preporuku studentu koga preporučuju.

Gospodinu Sutclifu smo rekli da smatramo da je najbolje da stipendije koriste svršeni studenti i to u vidu specijalizacije i sa nama se sasvim složio. Što se tiče samog studiranja on misli da bi za engleske studente bila interesantna slavistika i naša srednjovekovna umjetnost. Mišljenja smo da bi isto tako bilo interesantno studranje oceanografije i narodne muzike i folklora.

Zamolio nas je da sa ovom našom odlukom o dodeljivanju stipendije upoznate prof. Geoffrey Web-a, direktora Zavoda za 
zaštitu spomenika kulture Velike Britanije koji je 1951[.] godine boravio u našoj zemlji i prilično se upoznao sa našim kulturnim spomenicima, naročito u Srbiji i Makedoniji. Ukoliko bi se neki od stipendista odlučio da studira našu srednjovekovnu umjetnost možda bi bilo dobro neki od njegovih djaka dodje u obzir, jer je za ovo studiranje u našoj zemlji veoma važno prethodno biti upoznat sa našom srednjovekovnom umjetnošću. Molimo vas da ovo uzmete i obzir samo kao našu sugestiju.

Naknadno ćemo vam dostaviti upitnike koje će predložiti stipendisti treba da ispune i da nam dostave zajedno sa preporukom profesora kod koga su studirali i sa ostalim prilozima koji su označeni u Programu stipendija, koji vam u prilogu dostavljamo da biste mogli dati sva potrebna obaveštenja Britanskom Savetu po ovom pitanju.

Koristimo ovu priliku da potvrdimo vaše pismo Pov. 324/52 od 10[.] maja kojim ste nam dostavili molbu Keith Harfield-a za dodeljivanje stipendije radi usavršavanja znanja srpskohrvatskog jezika, koji traži zaposlenje u slučaju da ne dobije stipendiju. Što se zaposlenja tiče ono ne dolazi u obzir, a da bi mogli doneti odluku za dodeljivanje stipendije potrebno nam je pored ostalih podataka /uspjeh u učenju, politički stav itd./ vaše mišljenje odnosno predlog. Pošto su britanskim studentima dodeljene 3 stipendije to vas molimo da i ovu molbu rešavate u okviru tog broja dodeljenih stipendija.

Molimo vas da nas obavestite o svemu što je uradjeno po pitanju dodeljivanja stipendija britanskim studentima.

Smrt fašizmu - Sloboda narodu!

Za Načelnika odeljenja za naučne i kulturne veze sa inostranstvom, [potpisana] /Kr. Djordjević/ (AJ, 317-5-629) 


\section{Danijela Mitrović}

\section{THE CLASSIFIED DOCUMENTS OF THE CULTURAL COOPERATION OF THE FPRY WITH GREAT BRITAIN}

The paper presents the documentation available in the Fond of the Council of Culture and Science of the Federative People's Republic of Yugoslavia. The correspondence of the Embassy of the FPRY in London provides us with an invaluable insight into why the Yugoslav Government acted in a particular way. The explanations which have been left in the letters are a testimony of how the FPRY was to be presented, and to what extent it was important to have a good image of the country abroad. Traces of an oppressive and closely controlled system outside the country left their mark on the foreign affairs management and that is in the focus of the paper. The aim of this paper is to attempt the analysis of the documents to pinpoint the potential causes of the specific ways in which the FPRY Government acted, as well as highlighting the most pertinent aspects of cultural activities of the Embassy of the FPRY in London.

Key Words: the FPRY Government, the Embassy of the FPRY, cultural relationships, musical and performing arts, foreign affairs 